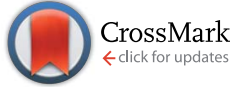

Cite this: RSC Adv., 2015, 5, 51413

\title{
Heavier group 2 metal complexes with a flexible scorpionate ligand based on 2-mercaptopyridine $\uparrow$
}

\author{
Kishor Naktode, ${ }^{a}$ Th. Dhileep N. Reddy, ${ }^{a}$ Hari Pada Nayek, ${ }^{b}$ Bhabani S. Mallik*a \\ and Tarun K. Panda*a
}

We report the synthesis of novel alkaline earth metal complexes $\left[\kappa^{2}-\mathrm{SS}-(\mathrm{Bmp})_{2} \mathrm{M}(\mathrm{THF})_{n}\right][\mathrm{M}=\mathrm{Ca}(2), \operatorname{Sr}(3) n$ $=2 ; \quad M=\mathrm{Ba}(4), n=3$ ] of a flexible dihydrobis(2-thiopyridone)borate (Bmp) ligand based on 2mercaptopyridine. Complexes 2-4 were isolated in good yield by the reaction between sodium dihydrobis(2-thiopyridone)borate, $\left[\{(\mathrm{Bmp}) \mathrm{Na}(\mathrm{THF})\}_{2}\right]_{n}$ (1) and the corresponding alkaline earth metal diiodides in toluene at ambient temperature. The solid-state structures of the strontium and barium complexes, complexes 3 and 4 respectively, were established using single-crystal X-ray diffraction analysis. The solid-state structure of sodium complex 1 was also confirmed using $X$-ray techniques. The solid-state structures of complexes 3 and 4 revealed that the Bmp ligand coordinates through sulphur atoms to the metal ions in $\kappa^{2}$ fashion. The strontium ion is attached symmetrically and the barium ion is asymmetrically linked with the Bmp ligand, manifesting the 2-thiopyridone and pyridine-2-thiolate tautomeric form of the Bmp ligand. The strontium ion in complex 3 adopts a distorted octahedral geometry whereas the geometry around the barium ion can best be described as a distorted pentagonal bipyramidal. Both complexes 3 and 4 also have a short $\mathrm{B} \cdots \mathrm{H} \cdots \mathrm{M}$ interaction due to the presence of the $\mathrm{BH}_{2}$ group in the ligand. In the solid state, sodium complex 1 is polymeric in nature and in the asymmetric unit each sodium ion is bonded to two sulphur atoms through $\eta^{1}$ and $\mu^{2}$ modes. The adjacent $\mathrm{BH}_{2}$ group is also linked with each sodium ion through hydrogen atoms via $\mu^{2}$ and $\eta^{1}$.

Received 17th March 2015 Accepted 3rd June 2015

DOI: $10.1039 / \mathrm{c} 5 \mathrm{ra0} 4696 \mathrm{c}$

www.rsc.org/advances not observed in the analogous Tp compounds. ${ }^{7}$ Recently, Owen and co-workers have developed a new family of scorpionate ligands based on boro-mercaptopyridine hydrotris(2thiopyridone)borate (Tmp) and hydrobis(2-thiopyridone)borate (Bmp) to study their properties of coordination to transition metals such as copper, ruthenium, iridium, palladium and platinum. ${ }^{8,9}$ However, their work has been restricted within the transition metal chemistry. It has been observed that boromercaptopyridine based scorpionate ligands coordinate through sulphur atoms and hydrogen atoms present in $\mathrm{BH}$ or $\mathrm{BH}_{2}$ groups which point towards the metal centre. ${ }^{10}$ Some of these $\mathrm{B}-\mathrm{H} \cdots$ metal interactions have been found to be particularly strong and exhibit significant metal-hydride character and thus these complexes can be used for hydride migration between transition metal and boron centres and this process can be applied to metal-mediated transformations. ${ }^{11}$ However, various factors, such as a transition metal's ability to accept a hydride, the nature of ancillary ligands attached to it and favourable substituents at the metal centre govern the hydride migration between boron and metal centre. ${ }^{12}$

Another interesting feature of such ligands is that the boromercaptopyridine unit can undergo tautomerisation between 2thiopyridone and pyridine-2-thiolate forms where the electron density moves from the boron atom to the sulphur atom (Scheme 1). It has been reported that although the thione-
${ }^{a}$ Department of Chemistry, Indian Institute of Technology Hyderabad, Ordnance Factory Estate, Yeddumailaram 502205, Telangana, India. E-mail: tpanda@iith.ac. in; bhabani@iith.ac.in; Fax: +91 402301 6032; Tel: + 914023016036

${ }^{b}$ Department of Applied Chemistry, Indian School of Mines, Dhanbad, 826004, Jharkhand, India

$\dagger$ Electronic supplementary information (ESI) available. CCDC 1049442-1049444. For ESI and crystallographic data in CIF or other electronic format see DOI: 10.1039/c5ra04696c 


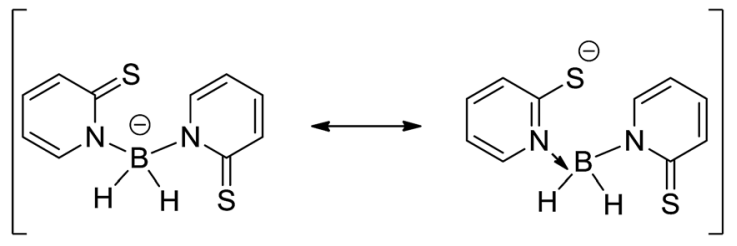

Scheme 1 Tautomeric forms of 2-thiopyridone and pyridine-2-thiolate of Bmp.

thiolate tautomeric equilibrium generally favours the thione form, there is a strong dependence on its environment with only a small difference in the energy between the two tautomeric forms. ${ }^{13}$

In our continuous study of the alkaline earth metal chemistry, our work focuses on the exploration of synthetic methodologies allowing for a facile, clean, high-yield production of the required molecules and determination of their molecular structure and function. We have recently introduced various amidophosphine chalcogenide and borane ligands containing $\mathrm{N}, \mathrm{E}\left(\mathrm{E}=\mathrm{O}, \mathrm{S}, \mathrm{Se}, \mathrm{BH}_{3}\right)$ and $\mathrm{P}$ as donor atoms into alkaline earth metal chemistry in order to study their coordination properties. ${ }^{14}$ These unique ligands are potentially capable of coordinating through hard nitrogen and phosphorus donor atoms along with the soft E donor atom. As the Bmp ligand has some resemblance to amidophosphine chalcogenide ligands in terms of hard and soft donor atoms (N, P, S), we have sought to introduce the Bmp ligand into electropositive alkaline earth metal chemistry in order to understand its thermodynamic stability.

Here, we report the syntheses and structural details of 2mercaptopyridine based scorpionate calcium, strontium and barium complexes of compositions $\left[\kappa^{2}-\left\{\left(2-\mathrm{SC}_{5} \mathrm{H}_{4} \mathrm{~N}\right)_{2}\left(\mathrm{BH}_{2}\right)\right\}_{2}\right.$ $\left.\mathrm{M}(\mathrm{THF})_{n}\right][\mathrm{M}=\mathrm{Ca}(2), \mathrm{Sr}(3) n=2 ; \mathrm{M}=\mathrm{Ba}(4), n=3]$. We also report the solid-state structure of the sodium complex $\left[\left\{\left(2-S-\mathrm{C}_{5} \mathrm{H}_{4} \mathrm{~N}\right)_{2}\left(\mathrm{BH}_{2}\right) \mathrm{Na}(\mathrm{THF})\right\}_{2}\right]_{n}$ (1). In addition, we also describe the comparative study among the computed structures and experimental structures of strontium and barium complexes.

\section{Results and discussion}

\section{Sodium complex}

The Owen group has reported on the sodium salt of the Bmp ligand; however, its solid-state structure has not been established. ${ }^{8 a}$ We found this very useful to report the solid-state structure of NaBmp and compare with the solid-state structures of alkaline earth metal complexes. The sodium complex (1) was prepared according to the procedure ${ }^{8 a}$ described by Owen et al. involving the reaction of $\mathrm{NaBH}_{4}$ and two equivalents of 2-mercaptopyridine in a mixture of toluene and THF at $80{ }^{\circ} \mathrm{C}$ for 12 hours (Scheme 2). The ${ }^{1} \mathrm{H},{ }^{13} \mathrm{C}\left\{{ }^{1} \mathrm{H}\right\}$ and ${ }^{11} \mathrm{~B}\left\{{ }^{1} \mathrm{H}\right\}$ NMR data for complex 1 are in full agreement with the values in literature. Complex 1 was re-crystallised from concentrated THF solution at $15{ }^{\circ} \mathrm{C}$ and the solid-state structure was confirmed using single-crystal X-ray structure analysis.
Complex 1 crystallises in the triclinic space group $P \overline{1}$, with two molecules in the unit cell. The data collection parameters are set out in Table 1. Fig. 1 shows the molecular structure of complex 1, as well as the grown-up structure. The solid-state structure of sodium complex 1 confirmed the $\kappa^{2}$ SScoordination of the Bmp ligand.

In the molecular structure of $\mathbf{1}$, it is evident that the complex is polymeric and has two different chemical environments for two sodium ions in the asymmetric unit of the molecule. The central sodium ions $\mathrm{Na} 1$ and $\mathrm{Na} 2$ are ligated from the Bmp ligand through the soft donor sulphur atoms S1, $\mathrm{S} 3$ in a $\kappa^{2}$ fashion. Moreover, Na1 and Na2 are bonded to third sulphur atom S4 and S2 respectively (Fig. 1b). The other sodium ion $\mathrm{Na} 2$ is also bonded with three sulphur atoms (S1, S2 and S3) from another Bmp fragment in the $\kappa^{2}$ mode. However, both the sodium atoms ( $\mathrm{Na} 1$ and $\mathrm{Na} 2$ ) are connected through a sulphur atom (S1) from the second Bmp ligand through a $\mu$ bridging mode, with a distance of $3.953 \AA$ between the sodium atoms. The Na-S bond distances [2.882(14) and 2.923(14) $\mathrm{A}]$ are similar, which demonstrates the 2-thiopyridone of the ligand. However, the Na1-S1 and Na2-S3 distances [2.815(1) and 2.789(2) A] indicate a strong attachment between the sodium ions and adjacent Bmp ligands with a symmetry element $[x+1, y, z]$ to grow the polymeric chain. Two eight-membered metallocycles Na1-S3-C14-N3-B1-N4C16-S4 and Na2-S1-C1-N1-B2-N2-C6-S2 are observed due to the coordination of the sulphur atoms of the Bmp ligand to the sodium ions. It is noteworthy that the sulphur atoms are coplanar with their pyridine rings ( $\mathrm{S} 1$ is coplanar with $\mathrm{C} 1-\mathrm{C} 2-$ C3-C5-C6-N1 and S2 is coplanar with C6-C7-C8-C9-C10-N2) and the two planes are almost orthogonal (the dihedral angle is $80.9^{\circ}$ ), indicating a significant contribution from the 2 -thiopyridone tautomeric form (Scheme 1). In addition, each sodium atom is coordinated with one THF molecule and the geometry around the sodium ions can be best described as a distorted tetrahedral. Both the $\mathrm{BH}_{2}$ groups from the $\mathbf{B m p}$ ligands are bonded with the sodium ions through hydrogen atoms via $\mu$ (H1B and $\mathrm{H} 2 \mathrm{~B})$ and $\eta^{1}$ (H1A and $\left.\mathrm{H} 2 \mathrm{~A}\right)$ bonds. The short Na $\cdots$ H-B distances (Na1-H1B $2.488 \AA$ A, Na2-H1B $2.544 \AA$ and $\mathrm{Na} 2-\mathrm{H} 2 \mathrm{~B} 2.503 \AA$ ) are in agreement with the linkage between $\mathrm{BH}_{2}$ and sodium ions. ${ }^{15}$ The second sodium atom and one sulphur atom of the Bmp fragment leads the polymeric chain. In the NMR spectra of 1 , only one set of signals in ${ }^{1} \mathrm{H}$, ${ }^{31} \mathrm{C}\left\{{ }^{1} \mathrm{H}\right\}$ and ${ }^{11} \mathrm{~B}\left\{{ }^{1} \mathrm{H}\right\}$ was obtained due to the fluxional nature of the molecule in the solution.

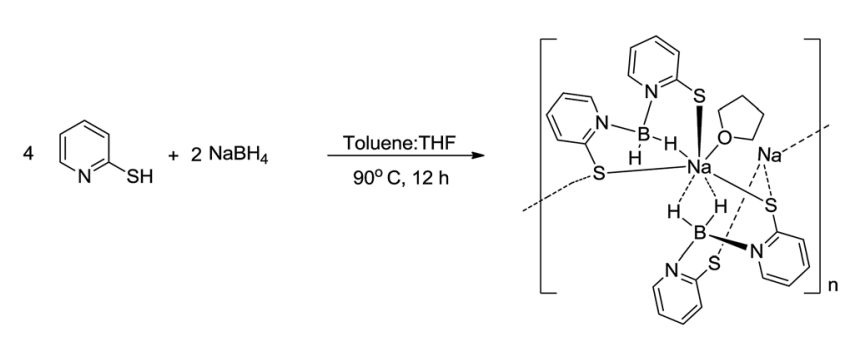

Scheme 2 Synthesis of sodium complex 1. 
Table 1 Crystallographic data and structure refinement parameters for complexes 1, 3 and 4

\begin{tabular}{|c|c|c|c|}
\hline Crystal & 1 & 3 & 4 \\
\hline CCDC no. & 1049442 & 1049443 & 1049444 \\
\hline Empirical formula & $\left(\mathrm{C}_{28} \mathrm{H}_{36} \mathrm{~B}_{2} \mathrm{~N}_{4} \mathrm{Na}_{2} \mathrm{O}_{2} \mathrm{~S}_{4}\right)_{n}$ & $\mathrm{C}_{28} \mathrm{H}_{36} \mathrm{~B}_{2} \mathrm{~N}_{4} \mathrm{O}_{2} \mathrm{~S}_{4} \mathrm{Sr}$ & $\mathrm{C}_{32} \mathrm{H}_{44} \mathrm{~B}_{2} \mathrm{BaN}_{4} \mathrm{O}_{3} \mathrm{~S}_{4}$ \\
\hline$T(\mathrm{~K})$ & $150(2)$ & $150(2)$ & $150(2)$ \\
\hline$\lambda(\AA)$ & 1.54184 & 0.71073 & 0.71073 \\
\hline Crystal system & Triclinic & Monoclinic & Monoclinic \\
\hline$b(\AA)$ & $11.0214(7)$ & $11.7200(9)$ & $17.7876(6)$ \\
\hline$c(\AA)$ & $20.0676(13)$ & $14.443(4)$ & $20.3426(6)$ \\
\hline$\alpha\left({ }^{\circ}\right)$ & $83.276(5)$ & 90 & 90 \\
\hline$\beta\left({ }^{\circ}\right)$ & $86.959(5)$ & $119.400(16)$ & $132.543(2)$ \\
\hline$\gamma\left({ }^{\circ}\right)$ & $86.536(5)$ & 90 & 90 \\
\hline$V\left(\AA^{3}\right)$ & $1629.82(17)$ & $1623.5(5)$ & $3666.9(2)$ \\
\hline Theta range for data collection & 4.04 to 70.85 & 3.24 to 29.00 & 2.95 to 29.02 \\
\hline \multirow[t]{3}{*}{ Limiting indices } & $-8 \leq h \leq 8$ & $-9 \leq h \leq 14$ & $-18 \leq h \leq 12$ \\
\hline & $-9 \leq k \leq 13$ & $-13 \leq k \leq 14$ & $-22 \leq k \leq 8$ \\
\hline & $-24 \leq l \leq 20$ & $-19 \leq l \leq 9$ & $-18 \leq l \leq 27$ \\
\hline Reflections collected/unique & $11474 / 6129[R(\mathrm{int})=0.0264]$ & $7191 / 3703[R(\mathrm{int})=0.0217]$ & $13294 / 7867[R($ int $)=0.0317]$ \\
\hline Completeness to theta & $97.5 \%$ & $86.1 \%$ & $95.6 \%$ \\
\hline Absorption correction & Semi-empirical & Semi-empirical & Semi-empirical \\
\hline Max. and min. transmission & 0.906 and 0.886 & 1.00000 and 0.91344 & 1.00000 and 0.84776 \\
\hline Refinement method & Full-matrix least-squares on $F^{2}$ & Full-matrix least-squares on $F^{2}$ & Full-matrix least-squares on $F^{2}$ \\
\hline Data/restraints/parameters & 1.00000 and 0.79802 & $3703 / 0 / 187$ & $7159 / 30 / 416$ \\
\hline Goodness-of-fit on $\mathrm{F}^{2}$ & 1.090 & 1.040 & 1.038 \\
\hline Final $R$ indices $[I>2 \sigma(I)]$ & $R_{1}=0.0738, \mathrm{w} R_{2}=0.2283$ & $R_{1}=0.0374, \mathrm{w} R_{2}=0.0784$ & $R_{1}=0.0365, \mathrm{w} R_{2}=0.0596$ \\
\hline
\end{tabular}

\section{Alkaline earth metal complexes}

Determining the structure and reactivity of alkaline earth metal species is an important step in the design and development of efficient catalysts; however, full realisation of the catalytic potential of these elements requires substantial advances in understanding their basic coordination and organometallic chemistry. ${ }^{16}$ The heavier alkaline earth metal complexes 2-4 were readily prepared in high yield by the reaction between the sodium salt (1) and corresponding alkaline earth metal diiodides in THF solvent at ambient temperature (Scheme 3). The pure complexes can be obtained from re-crystallisation of the crude compound from a concentrated solution of THF. All the complexes are air- and moisture-sensitive and sparingly soluble in aromatic solvents such as benzene and toluene. All three compounds were characterised using the spectroscopic/ analytic technique and the solid-state structure of complexes 3 and $\mathbf{4}$ were established through single-crystal X-ray diffraction analysis.
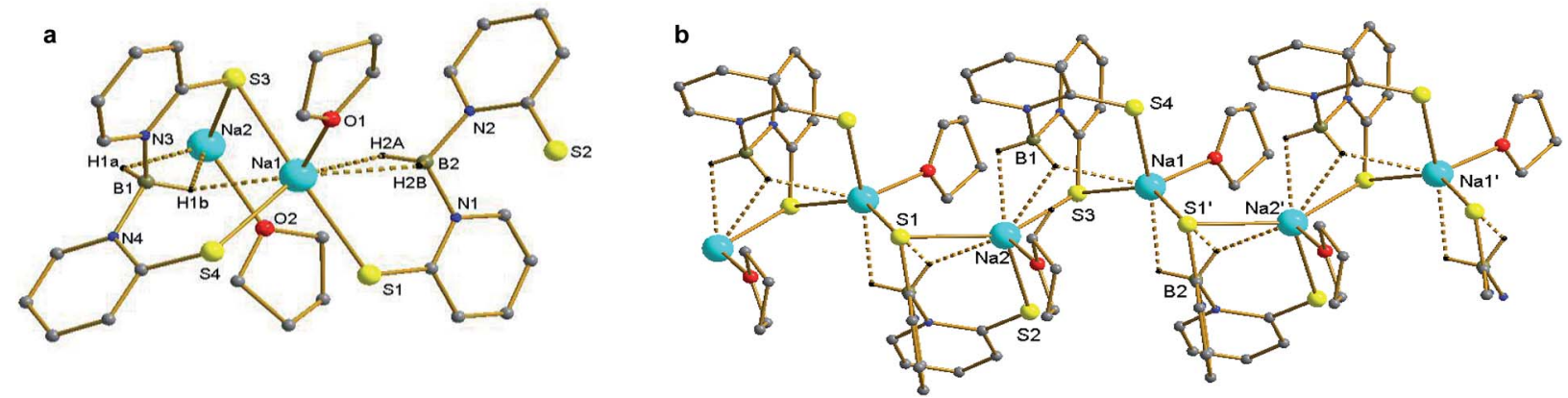

Fig. 1 (a) Solid-state molecular structure of complex 1 (b) fragment of one-dimensional of polymer of complex 1 . Hydrogen atoms (except H1A, $\mathrm{H} 1 \mathrm{~B}, \mathrm{H} 2 \mathrm{~A}$ and $\mathrm{H} 2 \mathrm{~B}$ ) are omitted for clarity. Colour code: cyan $\mathrm{Na}$, red $\mathrm{O}$, blue $\mathrm{N}$, grey $\mathrm{C}$ and black $\mathrm{H}$. 

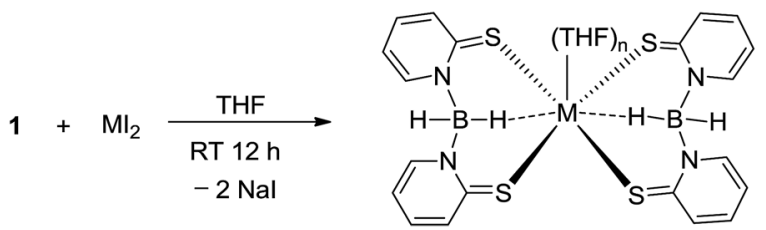

$M=C a(2), S r,(3) n=2 ; B a,(4) n=3$

Scheme 3 Synthesis of alkaline earth metal complexes 2-4.

The ${ }^{1} \mathrm{H}$ NMR spectra of complexes 2-4 measured in DMSO- $d_{6}$ was particularly broad, revealing four signals (from $\delta 8.56$ to $6.44 \mathrm{ppm}$ for $2,8.57$ to $6.43 \mathrm{ppm}$ for 3 and 8.77 to $6.43 \mathrm{ppm}$ for 4), each with an integration of three protons corresponding to the pyridine ring protons. A very broad signal for each complex, centred at $\delta 3.4 \mathrm{ppm}$ (for 2), $3.59 \mathrm{ppm}$ (for 3 ) and $3.52 \mathrm{ppm}$ (for 4), with integration of two protons, can be assigned to the two B-H protons present in the Bmp ligand. The broad resonances ( $\delta 3.58$ and $1.74 \mathrm{ppm}$ for $2,3.58$ and $1.1 .74 \mathrm{ppm}$ for 3 and 3.59 and $1.71 \mathrm{ppm}$ for 4 ) are due to the THF protons, which are coordinated to the metal ions. From the integration it can be calculated that there are two coordinated THF molecules in the calcium and strontium complexes, whereas three THF molecules are attached to the barium ion in complex 4 . In the ${ }^{13} \mathrm{C}$ $\left\{{ }^{1} \mathrm{H}\right\}$ NMR spectrum, each of the complexes 2-4 displayed five characteristic signals in the low-field region of the spectra. The chemical shift corresponding to the $C=\mathrm{S}$ group was found at $\delta$ 182.5 (for 2), 182.4 (for 3) and 182.9 (for 4) ppm. Similar chemical shift values were obtained for the complex $\left[\operatorname{Rh}\left\{\kappa^{3}-\right.\right.$ $\left.\left.(\mathrm{Bmp})_{2}\right\}\left(\eta^{3}-\mathrm{C}_{8} \mathrm{H}_{13}\right)\right](179.9 \mathrm{ppm})$ reported by Owen et al. ${ }^{9 a}$ The infrared spectra of complexes 2-4 showed a characteristic absorption band at 2354 (for 2), 2387 (for 3) and 2375 (for 4) $\mathrm{cm}^{-1}$ for the terminal B-H stretch, which is consistent with the reading of $2422 \mathrm{~cm}^{-1}$ reported for $\left[\mathrm{Rh}\left\{\kappa^{3}-(\mathrm{Bmp})_{2}\right\}\left(\eta^{3}-\mathrm{C}_{8} \mathrm{H}_{13}\right)\right] \cdot{ }^{9 a}$ In the ${ }^{11} \mathrm{~B}\left\{{ }^{1} \mathrm{H}\right\}$ NMR experiment for each of the complexes 2-4, a broad resonance signal at $\delta 1.11$ (for 2), 0.82 (for 3) and 1.73 (for 4) ppm is observed.

Although there has been continued interest in alkaline earth organo metallics, ${ }^{17 a}$ particularly in the cyclopentadienyl chemistry of these elements, ${ }^{17 b}$ complexes $\mathbf{2 - 4}$ represent, to the best of our knowledge, the first structurally characterised alkaline earth metal complexes of the Bmp ligand. Therefore, their molecular structures in the solid state were determined using $\mathrm{X}$ ray diffraction analysis. X-ray quality single crystals were obtained from the concentrated THF solution of each of the complexes. Complex 2 was found to diffract very weakly under X-ray and data are therefore not publishable. The molecular structures of the strontium and barium complexes are established. Both the complexes $\mathbf{3}$ and $\mathbf{4}$ crystallise in the monoclinic space group $P 2_{1} / c$, with two and four molecules respectively in the respective unit cell. The data collection parameters are set out in Table 1. Fig. 2 and 3 display the molecular structure of strontium complex 3 and barium complex 4 respectively. The solid-state structures of $\mathbf{3}$ and $\mathbf{4}$ confirmed a $\kappa^{2}$-SS coordination mode for Bmp. In complexes 3, Sr1 ion is bonded with four sulphur atoms, $\mathrm{S} 1, \mathrm{~S} 2, \mathrm{~S}^{\prime}(-x+1,-y,-z)$ and $\mathrm{S}^{\prime}(-x+1,-y$, $-z)$ from two Bmp ligands. Ba1 is connected to four crystallographically independent sulphur atoms ( $\mathrm{Sa}, \mathrm{S} 2, \mathrm{~S} 3$ and S4) in complex 4. In addition, in complex 3 , the strontium ion is coordinated to two THF molecules to adopt a distorted octahedral geometry. In contrast, the barium ion in complex $\mathbf{4}$ is ligated with three THF molecules to adopt a distorted pentagonal bipyramidal geometry around it. The symmetric $\mathrm{Sr}-\mathrm{S}$ bond distances [3.0171(8) and 2.9909(10) $\AA]$ in complex 3 are in agreement with reported $\mathrm{Sr}-\mathrm{S}$ bond lengths $[2.951(2) \AA]$ in $[\mathrm{Sr}$ $\left.\left\{\mathrm{S}\left(2,4,6-t \mathrm{Bu}_{3} \mathrm{C}_{6} \mathrm{H}_{2}\right)\right\}_{2}(\mathrm{THF})_{4}\right]^{18}$ and $[3.025(3) \AA]$ in $\left[\mathrm{Sr}_{3}\left(\mathrm{OCSOC}_{2^{-}}\right.\right.$ $\left.\left.\mathrm{H}_{5}\right)_{6}\left(\mathrm{C}_{2} \mathrm{H}_{5} \mathrm{OH}\right)_{8}\right],{ }^{19}$ indicating a major contribution from the 2thiopyridone form of the Bmp ligands. In the barium complex, the $\mathrm{Ba}-\mathrm{S}$ distances are not symmetric and a combination of short [Ba1-S1 3.255(1) and Ba1-S4 3.273(1) §] and long [Ba1-S2 3.346(1) and Ba1-S3 3.449(4) $\AA]$ is observed. These sequences of short and long bond distances are in agreement with the Ba-S covalent and coordination bond respectively. ${ }^{20,21}$ Thus, it is evident that in complex 4, pyridine-2-thiolate tautomeric form of Bmp is the major contributor (Scheme 1). The variation in ion radii of strontium and barium presumably causes one particular tautomeric form of the 2-mercaptopyridine based scorpionate Bmp ligand. Similar observations were reported by Owen et $a .^{9}$ The larger $\mathrm{Ba}-\mathrm{S}$ distances, when compared to $\mathrm{Sr}-\mathrm{S}$ distances, are due to the larger ion radius of the barium ion $(1.35 \AA)$ when compared to the strontium ion $(1.12 \AA) .{ }^{22}$ In complex 3, two eight-membered metallocycles, Sr1-S1-C1-N1$\mathrm{B} 1-\mathrm{N} 2-\mathrm{C} 10-\mathrm{S} 2$ and $\mathrm{Sr}^{\prime}-\mathrm{S} 1^{\prime}-\mathrm{C} 1^{\prime}-\mathrm{N} 1^{\prime}-\mathrm{B} 1^{\prime}-\mathrm{N} 2^{\prime}-\mathrm{C} 10^{\prime}-\mathrm{S} 2^{\prime}$, (Ba1S1-C5-N1-B1-N2-C10-S2 and Ba2-S3-C11-N3-B2-N4-C20-S4 for complex 4), with a twist-boat configuration are formed by the $\kappa^{2}$ coordination of each Bmp ligand to the strontium ion. Both the sulphur atoms (S1 and S2) are coplanar with the respective pyridine planes (C1-C20-C3-C4-C5-N1 and C6-C7-C8-C9C10-N2) and they bisect each other through B1-N1 and B1-N2 bonds to make a dihedral angle of $76.44^{\circ}$. However, the four sulphur atoms in complex 4 are not coplanar with the pyridine planes and lie slightly above or below the planes (S1 $0.143 \AA$ above, S2 0.105 Å below, S3 0.137 Å below and S4 0.170 Å below), indicating the formation of thiolate for the Bmp ligands. Two sets of B-N distances [1.56(2) and 1.60(2) $\AA$ ] in the Bmp ligands in complex 4 are observed, also indicating the asymmetric nature of the ligand backbone. However, only one kind of B-N distance [1.575(3)] is observed to support symmetric nature of the Bmp ligand backbone present in complex 3. Two short $\mathrm{Sr} \cdots$ $\mathrm{H}-\mathrm{B}$ contacts $(2.806 \AA)$ are observed due to the secondary interaction between the strontium ion and $\mathrm{BH}_{2}$ hydrogen atoms. Analogous short $\mathrm{Ba} \cdots \mathrm{H}-\mathrm{B}$ contacts (2.706 and $2.728 \AA$ ) are obtained due to the secondary interaction between the barium ion and one hydrogen atom from the $\mathrm{BH}_{2}$ group. Such alkaline earth metal and hydrogen interactions are observed in complex $\left[\mathrm{M}\left\{\mathrm{N}\left(2,4,6-\mathrm{Me}_{3} \mathrm{C}_{6} \mathrm{H}_{2}\right)-\mathrm{SiMe}_{3}\right\}_{2}(\mathrm{PMTDA})\right](\mathrm{M}=\mathrm{Sr}, \mathrm{Ba}$ and PMDTA $=N, N, N^{\prime}, N^{\prime \prime}, N^{\prime \prime}$ pentamethyldiethylenetriamine) and reported in literature. ${ }^{23}$

\section{Computational analysis}

First principles calculations were performed to investigate the structure and coordination properties of various metal 


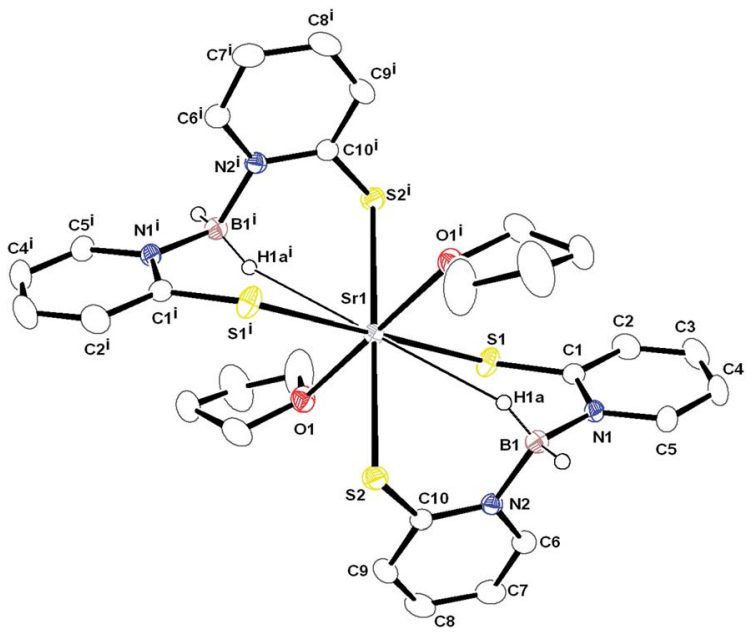

Fig. 2 Solid-state structure of complex 3 and ellipsoids are drawn to encompass $50 \%$ probability. Hydrogen atoms (except $\mathrm{H} 1 \mathrm{a}, \mathrm{H} 1 \mathrm{~b}, \mathrm{H} 1 \mathrm{a}^{\mathrm{i}}$ and $\mathrm{H} \mathrm{b}^{\mathrm{i}}$ ) are omitted for clarity. Selected bond lengths $[\AA]$ and bond angles [ ${ }^{\circ}$ ]: Sr1-S1 3.0171(8), Sr1-S2 2.991(1), Sr1-O1 2.552(2), Sr1-O1' 2.552(2), Sr1-S1' 3.0171(8), Sr1-S2' 2.991(1). More bond lengths and angles are given in ESI.†

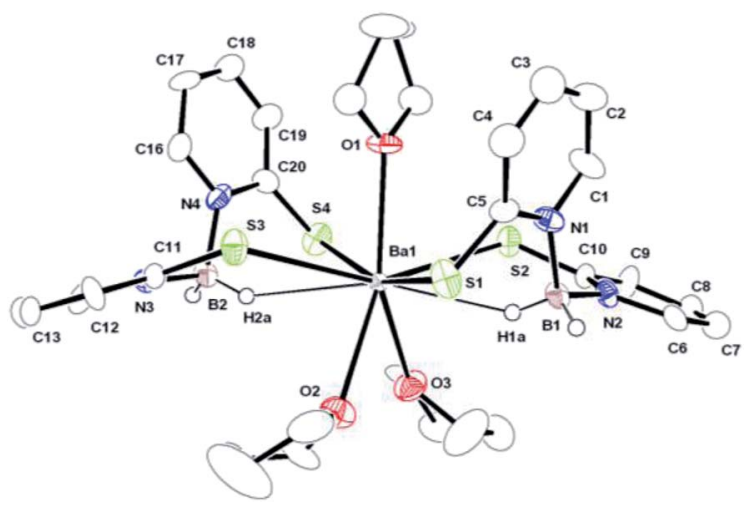

Fig. 3 Solid-state structure of complex 4 and ellipsoids are drawn to encompass $50 \%$ probability. Hydrogen atoms are omitted for clarity (except $\mathrm{H} 1 \mathrm{~b}, \mathrm{H} 1 \mathrm{a}, \mathrm{H} 2 \mathrm{a}$ and $\mathrm{H} 2 \mathrm{~b}$ ). Selected bond lengths $[\AA]$ and bond angles [ ${ }^{\circ}$ ]: Ba1-S1 3.255(2), Ba1-S2 3.346(1), Ba1-S3 3.449(1), Ba1-S4 3.273(2), Ba1-O1 2.711(2), Ba1-O2 2.794(4), Ba1-O3 2.797(3). More bond lengths and angles are given in ESI. $\dagger$

complexes described in the Experimental section of the current study. We were also interested in modelling the elusive calcium complex whose crystals weakly diffracted in X-ray. In addition, we wanted more insight about the structures and bonding of the sodium, strontium and barium complexes by optimising their structure computationally. The chemical nature of bonds between metal and ligands, as well as solvent, was investigated to understand the coordinating behaviour of metal ions. All the model structures were drawn in GaussView ${ }^{24}$ and optimised at B3LYP/LANL2DZ level ${ }^{25}$ of electronic structure calculation using the Gaussian 09 (Rev B.01) software. ${ }^{26}$ The chosen method, combining hybrid density functional and potential for the metals studied here, has been used in earlier studies involving alkaline earth metal complexation. ${ }^{27}$ We computed the structures, shown in Fig. 4, by following the geometry optimisation procedure. The coordinating environments of metal ions are very similar to the experimentally obtained complex structures for ions other than $\mathrm{Ca}$.

A comparison of computed bonds and angles and available experimental data is given in the ESI. $\uparrow$ The distances and angles are close to the crystal structure data obtained using X-ray diffraction analysis. For example, calculated $\mathrm{Na}-\mathrm{S}$ and $\mathrm{Na}-\mathrm{O}$ distances are 2.99 and $2.27 \AA$, whereas the experimental values are 2.892 and $2.329 \AA$, respectively. Table 2 represents the comparison of calculated and experimentally obtained values corresponding to significant coordinating distances around the ions. The symmetric Sr-S bond distances are slightly higher than the experimental values. As observed from earlier discussions, the calculated $\mathrm{Ba}-\mathrm{S}$ distances in barium complexes are not symmetric and the differences are within $0.2 \AA$ as compared to measured ones. The geometry around calcium shows behaviour similar to that of strontium due to similar ionic radii between the two metal ions. However the Ca-S (3.04-3.10 $⿱$ ) and $\mathrm{Ca}-\mathrm{O}(2.44 \AA)$ distances fall in the range similar to those $[2.818(3) \AA$ and $2.495 \AA]$ obtained for $\left[\left\{2,4,6-(t \mathrm{Bu})_{3} \mathrm{C}_{6} \mathrm{H}_{2} \mathrm{~S}\right\}\right.$ $\left.\mathrm{Ca}(\mathrm{THF})_{4}\right]$ reported by Ruhlandt-Senge et al. ${ }^{28}$ The adopted level of calculation can describe the $\mathrm{B}-\mathrm{H} \cdots \mathrm{M}$ interaction satisfactorily. The variation in ionic radii for alkaline earth metal ions plays a major role in the interaction of these metal ions with ligands as well as solvents. The $\mathrm{Sr}-\mathrm{S}$ distances are symmetric, but only two of the Ba-S distances are the same. Although Ca and $\mathrm{Sr}$ show similar interaction towards the solvent THF molecules, the $\mathrm{Ba}-\mathrm{O}$ distance is the highest among these three. We observed a clear trend of increase in $\mathrm{M}-\mathrm{S}$ distances as well as $\mathrm{M} \cdots \mathrm{H}\left(\mathrm{BH}_{2}\right)$ distances with the increase in ionic radii of metal

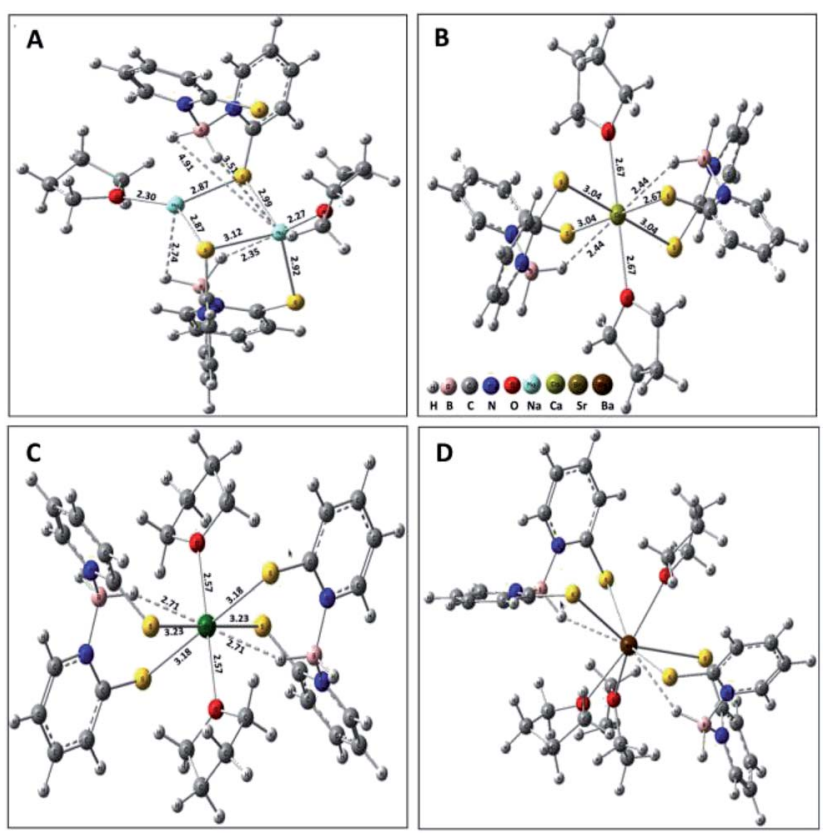

Fig. 4 Computed structures of complexes are shown in A, B, C and D corresponding to $\mathrm{Na}, \mathrm{Ca}, \mathrm{Sr}$ and $\mathrm{Ba}$, respectively. The coordinating bonds around the metals ions are shown in $\AA$ unit. 
Table 2 Comparison of computed $\mathrm{M}-\mathrm{O}, \mathrm{M}-\mathrm{S}$ and $\mathrm{M} \cdots \mathrm{H}$ distances with experimental values (where applicable) for the sodium, calcium, strontium and barium complexes

\begin{tabular}{|c|c|c|c|c|c|c|c|}
\hline \multirow{3}{*}{$\begin{array}{l}\text { Distance } \\
(\AA)\end{array}$} & \multicolumn{7}{|l|}{ M } \\
\hline & \multicolumn{2}{|l|}{$\mathrm{Na}$} & \multirow{2}{*}{$\frac{\mathrm{Ca}}{\mathrm{B} 3 \mathrm{LYP}}$} & \multicolumn{2}{|l|}{$\mathrm{Sr}$} & \multicolumn{2}{|l|}{$\mathrm{Ba}$} \\
\hline & B3LYP & Expt & & B3LYP & Expt & B3LYP & Expt \\
\hline \multirow[t]{3}{*}{$\mathrm{M}-\mathrm{O}$} & 2.27 & 2.329 & 2.44 & 2.57 & 2.552 & 2.75 & 2.702 \\
\hline & 2.30 & 2.330 & 2.44 & 2.57 & 2.552 & 2.80 & 2.805 \\
\hline & - & & - & - & & 2.80 & 2.813 \\
\hline \multirow[t]{4}{*}{ M-S } & 2.87 & 2.789 & 3.04 & 3.18 & 3.017 & 3.46 & 3.273 \\
\hline & 2.87 & 2.814 & 3.04 & 3.18 & 3.017 & 3.46 & 3.355 \\
\hline & 2.99 & 2.892 & 3.10 & 3.23 & 2.991 & 3.53 & 3.449 \\
\hline & 3.12 & 2.923 & 3.10 & 3.23 & 2.991 & 3.53 & 3.346 \\
\hline \multirow[t]{2}{*}{$\mathbf{M} \cdots \mathrm{H}$} & 2.74 & 2.497 & 2.67 & 2.71 & 2.806 & 2.84 & 2.729 \\
\hline & 2.35 & 2.488 & 2.67 & 2.71 & 2.806 & 2.84 & 2.743 \\
\hline
\end{tabular}

ions. Though experimental data for the Ca complex is not available, our computational calculations reveal that calcium can make shortest B-H $\cdots \mathrm{M}$ contact among the alkaline earth metal ions. The shortest $\mathrm{M} \cdots \mathrm{H}$ distances are $2.35,2.67,2.71$, and $2.84 \AA$ for $\mathrm{Na}, \mathrm{Ca}, \mathrm{Sr}$ and $\mathrm{Ba}$, respectively. It is noteworthy that the experimentally obtained value for the Ba complex is between those obtained for the $\mathrm{Na}$ and $\mathrm{Sr}$ complexes, indicating the stronger $\mathrm{M} \cdots \mathrm{H}$ interactions between barium and hydrogen atoms compared to other analogues. For a particular metal ion, the hydride interactions with two $\mathrm{BH}_{2}$ groups are similar, except for $\mathrm{Na}$, where we observed different types of such interactions due to the formation of polymeric forms.

\section{Experimental}

\section{General consideration}

All manipulations involving air- and moisture-sensitive organometallic compounds were carried out under argon using the standard Schlenk technique or argon-filled glove box. Hydrocarbon solvents (n-pentane, toluene) were distilled under nitrogen from $\mathrm{LiAlH}_{4}$ and stored in the glove box. THF was dried and deoxygenated by distillation over sodium benzophenone ketyl under argon and then distilled and dried over $\mathrm{CaH}_{2}$ prior to storing in the glove box. Dimethylsuphoxide (DMSO- $d_{6}$ ) was dried over $\mathrm{CaH}_{2}$, distilled and stored in the glove box. ${ }^{1} \mathrm{H}$ NMR (400 MHz), ${ }^{13} \mathrm{C}\left\{{ }^{1} \mathrm{H}\right\}$ NMR (100 MHz) and ${ }^{11} \mathrm{~B}\left\{{ }^{1} \mathrm{H}\right\}(128.3 \mathrm{MHz})$ spectra were measured on a BRUKER AVANCE III-400 spectrometer. Elemental analyses were performed on a BRUKER EURO EA at the Indian Institute of Technology Hyderabad. Sodium dihydrobis(2-thiopyridone)borate (1) was prepared according to procedures prescribed in the literature. ${ }^{8 a}$

General preparation of $\left[\kappa_{2}-\left\{\left(2-\mathrm{SC}_{5} \mathrm{H}_{4} \mathbf{N}\right)_{2}-\left(\mathrm{BH}_{2}\right)\right\}_{2} \mathrm{M}(\mathrm{THF})_{n}\right]$ : $\mathbf{M}=\mathbf{C a}(2), \operatorname{Sr}(3) n=2 ; \mathbf{M}=\mathbf{B a}(4), n=3]$

A $25 \mathrm{~mL}$ Schlenk flask was charged with one equivalent of alkaline earth metal diiodide and two equivalents of sodium dihydrobis(2-thiopyridone)borate (1). $10 \mathrm{~mL}$ of THF was added to it and the reaction mixture was kept for stirring at ambient temperature for 12 hours. White precipitate of sodium iodide was separated through a G4 frit. The solvent was evaporated to dryness under vacuo to give a green residue. The title compounds were re-crystallised from THF at $-35{ }^{\circ} \mathrm{C}$.

$\mathbf{M}=\mathbf{C a}$ (2). Yield $144 \mathrm{mg} 65 \% .{ }^{1} \mathrm{H}$ NMR (400 MHz, DMSO- $d_{6}$, $\left.25^{\circ} \mathrm{C}\right): \delta 8.56\left[\mathrm{dd}, 4 \mathrm{H},{ }^{3} J_{\mathrm{HH}}=6.2 \mathrm{~Hz},{ }^{4} \mathrm{~J}_{\mathrm{HH}}=1.2 \mathrm{~Hz},{ }^{\mathrm{mp}} \mathrm{CH}-(6)\right]$, $7.12\left[\mathrm{~d}, 4 \mathrm{H},{ }^{3} J_{\mathrm{HH}}=8.2 \mathrm{~Hz},{ }^{\mathrm{mP}} \mathrm{CH}-(3)\right], 7.02\left[\tau \mathrm{d}, 4 \mathrm{H},{ }^{3} J_{\mathrm{HH}}=6.8 \mathrm{~Hz}\right.$, $\left.{ }^{4} J_{\mathrm{HH}}=1.8 \mathrm{~Hz},{ }^{\mathrm{mp}} \mathrm{CH}-(4)\right], 6.44\left[\tau \mathrm{d}, 4 \mathrm{H},{ }^{3} J_{\mathrm{HH}}=6.5 \mathrm{~Hz},{ }^{4} J_{\mathrm{HH}}=1.3\right.$ $\left.\mathrm{Hz},{ }^{\mathrm{mp}} \mathrm{CH}(5)\right], 3.58$ (THF), 3.40 (br, 2H, $\left(\mathrm{BH}_{2}\right)$ )], 1.74 (THF) ppm. ${ }^{11} \mathrm{~B}\left\{{ }^{1} \mathrm{H}\right\}$ NMR $\left(128.3 \mathrm{MHz}\right.$, DMSO- $\left.d_{6}, 25{ }^{\circ} \mathrm{C}\right): \delta 1.11 \mathrm{ppm} .{ }^{13} \mathrm{C}\left\{{ }^{1} \mathrm{H}\right\}$ NMR (100.6 MHz, DMSO- $\left.d_{6}, 25{ }^{\circ} \mathrm{C}\right): \delta 182.5(C=\mathrm{S}), 150.5\left[{ }^{\mathrm{mP}} \mathrm{CH}-\right.$ (6)], 133.8 [ $\left.{ }^{\mathrm{mp}} \mathrm{CH}-(3)\right], 133.1$ [ $\left.{ }^{\mathrm{mp}} \mathrm{CH}-(4)\right], 109.8$ [ $\left.{ }^{\mathrm{mp}} \mathrm{CH}-(5)\right], 66.9$ (THF), 25.0 (THF) ppm. FTIR (selected peaks): 2354 (w, B-H), 1607 (s), 1533 (s), 1259 s, 753 (s), 554 (m) cm cm $^{-1}$ Elemental analysis calculated (\%) for $\left(\mathrm{C}_{28} \mathrm{H}_{36} \mathrm{~B}_{2} \mathrm{~N}_{4} \mathrm{O}_{2} \mathrm{~S}_{4} \mathrm{Ca}\right)$ (650.57): C 51.69, H 5.58, N 8.61; found C 51.28, H 5.33, N 8.39.

$\mathbf{M}=\mathbf{S r}$ (3). Yield $133 \mathrm{mg} 65 \% .{ }^{1} \mathrm{H}$ NMR (400 MHz, DMSO- $d_{6}$, $\left.25{ }^{\circ} \mathrm{C}\right): \delta 8.57\left[\mathrm{~d}, 4 \mathrm{H},{ }^{3} J_{\mathrm{HH}}=5.7 \mathrm{~Hz},{ }^{\mathrm{mp}} \mathrm{CH}-(6)\right], 7.19\left[\mathrm{~d}, 4 \mathrm{H},{ }^{3} J_{\mathrm{HH}}\right.$ $\left.=5.7 \mathrm{~Hz},{ }^{\mathrm{mp}} \mathrm{CH}-(3)\right], 7.12\left[\mathrm{~d}, 4 \mathrm{H},{ }^{3} \mathrm{~J}_{\mathrm{HH}}=8.0 \mathrm{~Hz},{ }^{\mathrm{mP}} \mathrm{CH}-(4)\right], 6.43$ $\left[\mathrm{dd}, 4 \mathrm{H},{ }^{3} J_{\mathrm{HH}}=6.2 \mathrm{~Hz},{ }^{4} J_{\mathrm{HH}}=1.0 \mathrm{~Hz},{ }^{\mathrm{mP}} \mathrm{CH}-(5)\right], 3.59(\mathrm{br}, 2 \mathrm{H}$, $\left.\left(\mathrm{B} H_{2}\right)\right)$ ], 3.56 (THF), 1.74 (THF) ppm. ${ }^{11} \mathrm{~B}\left\{{ }^{1} \mathrm{H}\right\}$ NMR (128.3 MHz, DMSO- $\left.d_{6}, 25{ }^{\circ} \mathrm{C}\right): \delta 0.82 \mathrm{ppm} .{ }^{13} \mathrm{C}\left\{{ }^{1} \mathrm{H}\right\}$ NMR (100.6 MHz, DMSO$\left.d_{6}, 25{ }^{\circ} \mathrm{C}\right): \delta 182.4(C=\mathrm{S}), 150.4\left[{ }^{\mathrm{mp}} \mathrm{CH}-(6)\right], 133.8\left[{ }^{\mathrm{mp}} \mathrm{CH}-(3)\right]$, 133.1 [ $\left.{ }^{\mathrm{mp}} \mathrm{CH}-(4)\right], 109.8$ [ $\left.{ }^{\mathrm{mp}} \mathrm{CH}-(5)\right], 67.0$ (THF), 25.0 (THF) ppm. FTIR selected value: 2496 (w), 2387 (w, B-H), 1608 (s), 1532 (s), 749 (s), $519(\mathrm{w}) \mathrm{cm}^{-1}$. Elemental analysis calculated (\%) for $\left(\mathrm{C}_{28} \mathrm{H}_{36} \mathrm{~B}_{2} \mathrm{~N}_{4} \mathrm{O}_{2} \mathrm{~S} 4 \mathrm{Sr}\right)$ (698.11): C 48.17, $\mathrm{H} \mathrm{5.20,} \mathrm{N} \mathrm{8.03;} \mathrm{found} \mathrm{C}$ 47.72, H 4.93, N 7.81.

$\mathbf{M}=\mathbf{B a}$ (4). Yield $142 \mathrm{mg} 68 \% .{ }^{1} \mathrm{H}$ NMR (400 MHz, DMSO- $d_{6}$, $25{ }^{\circ} \mathrm{C}$ ): $\delta 8.77\left[\mathrm{dd}, 4 \mathrm{H},{ }^{3} J_{\mathrm{HH}}=6.3 \mathrm{~Hz},{ }^{4} J_{\mathrm{HH}}=1.2 \mathrm{~Hz},{ }^{\mathrm{mp}} \mathrm{CH}-(6)\right]$, $7.13\left[\mathrm{~d}, 4 \mathrm{H},{ }^{3} J_{\mathrm{HH}}=7.9 \mathrm{~Hz},{ }^{\mathrm{mp}} \mathrm{CH}-(3)\right], 7.01\left[\mathrm{~d}, 4 \mathrm{H},{ }^{3} J_{\mathrm{HH}}=6.0 \mathrm{~Hz}\right.$, $\left.{ }^{\mathrm{mp}} \mathrm{CH}-(4)\right], 6.43\left[\mathrm{~d}, 4 \mathrm{H},{ }^{3} \mathrm{~J}_{\mathrm{HH}}=5.1 \mathrm{~Hz},{ }^{\mathrm{mp}} \mathrm{CH}-(5)\right], 3.59$ (THF), 3.52 (br, 2H, $\left.\left.\left(\mathrm{BH}_{2}\right)\right)\right], 1.71$ (THF) ppm. ${ }^{11} \mathrm{~B}\left\{{ }^{1} \mathrm{H}\right\}$ NMR $(128.3 \mathrm{MHz}$, DMSO- $\left.d_{6}, 25{ }^{\circ} \mathrm{C}\right): \delta 1.73 \mathrm{ppm} .{ }^{13} \mathrm{C}\left\{{ }^{1} \mathrm{H}\right\}$ NMR (100.6 MHz, DMSO$\left.d_{6}, 25{ }^{\circ} \mathrm{C}\right): \delta 182.9(C=\mathrm{S}), 150.6\left[{ }^{\mathrm{mp}} \mathrm{CH}-(6)\right], 134.0\left[{ }^{\mathrm{mp}} \mathrm{CH}-(3)\right]$, $132.8\left[{ }^{\mathrm{mp}} \mathrm{CH}-(4)\right], 109.6$ [ $\left.{ }^{\mathrm{mp}} \mathrm{CH}-(5)\right], 68.2$ (THF), 25.7 (THF) ppm. FTIR selected value: 2375 (w, B-H), 1604 (s), 1532 (s), 797 (s), 520 (w) $\mathrm{cm}^{-1}$. Elemental analysis calculated (\%) for $\left(\mathrm{C}_{32} \mathrm{H}_{44} \mathrm{~B}_{2} \mathrm{~N}_{4}\right.$ $\mathrm{O}_{3} \mathrm{~S}_{4} \mathrm{Ba}$ ) (819.93): C 46.88, H 5.41, N 6.83; found C 46.31, H 5.09, $\mathrm{N} 6.52$.

\section{X-ray crystallographic studies of complexes 1,3 and 4}

X-ray crystallographic analyses. Single crystals of complex 1 were obtained from a concentrated solution of THF at $15{ }^{\circ} \mathrm{C}$ while single crystals of complexes $\mathbf{3}$ and $\mathbf{4}$ were obtained from their respective concentrated THF solutions under argon atmosphere at a temperature of $-35^{\circ} \mathrm{C}$. In each case, a crystal of suitable dimensions was mounted on a CryoLoop (Hampton Research Corp.) with a layer of light mineral oil and placed in a nitrogen stream at 150(2) K. All measurements were made on an Agilent Supernova X-calibur Eos CCD detector with either graphite-monochromatic $\mathrm{Cu}-\mathrm{K} \alpha(1.54184 \AA$, for 1) or Mo-K $\alpha$ $(0.71073 \AA$ for 3 and 4) radiation. Crystal data and structure refinement parameters are summarised in Table 1 . The structures were solved by direct methods (SIR2004) ${ }^{29}$ and refined on $F^{2}$ using the full-matrix least-squares method, using SHELXL- 
97. ${ }^{30}$ Non-hydrogen atoms were anisotropically refined. $\mathrm{H}$-atoms were included in the refinement on calculated positions riding on their carrier atoms. The function minimised was $\left[\sum w\left(F_{\mathrm{o}}{ }^{2}-{F_{\mathrm{c}}}^{2}\right)^{2}\right]\left(w=1 /\left[\sigma^{2}\left(F_{\mathrm{o}}{ }^{2}\right)+(a P)^{2}+b P\right]\right)$, where $P=$ $\left(\operatorname{Max}\left(F_{\mathrm{o}}{ }^{2}, 0\right)+2{F_{\mathrm{c}}}^{2}\right) / 3$ with $\sigma^{2}\left({F_{\mathrm{o}}}^{2}\right)$ from counting statistics. The function $R_{1}$ and $\mathrm{w} R_{2}$ were $\left.\left(\Sigma|| F_{\mathrm{o}}|-| F_{\mathrm{c}} \mid\right)\right) / \Sigma\left|F_{\mathrm{o}}\right|$ and $\left[\Sigma w\left(F_{\mathrm{o}}{ }^{2}-\right.\right.$ $\left.\left.F_{\mathrm{c}}{ }^{2}\right)^{2} / \Sigma\left(w F_{\mathrm{o}}{ }^{4}\right)\right]^{1 / 2}$ respectively. The DIAMOND-3 and ORTEP-III programs were used to draw the molecule (ESI). $\dagger$

\section{Conclusion}

To sum up, we have reported the syntheses of calcium, strontium and barium complexes of the Bmp ligand. In the solidstate structure of the strontium complex 3, a symmetric attachment, $\kappa^{2}$, of the Bmp ligand to the metal ion is observed. However, an asymmetric $\kappa^{2}$ SS-ligation of $\mathbf{B m p}$ to the barium ion is observed in complex 4. These symmetric and asymmetric attachments are the manifestation of two tautomeric forms, 2thiopyridone and pyridine-2-thiolate, of the Bmp ligand. We also observed that the sodium complex of the Bmp ligand is polymeric in the solid state. Our computational study also matches well with our experimental observations; in addition, the calculated calcium complex structure is also in agreement with the higher analogues of $\mathrm{Sr}$ and $\mathrm{Ba}$ complexes.

\section{Acknowledgements}

This work is supported by the Ministry of New and Renewable Energy (MNRE), India under project no. 103/209/2013-NT, dated: 29th September, 2014. The instrumental facilities were provided by the Indian Institute of Technology Hyderabad (IITH). K. N. and Th. D. N. R. thank the University Grants Commission (UGC), India, for his PhD fellowship. We sincerely thank Prof. Kazushi Mashima and Dr Hayato Tsurugi, Osaka University, for their generous support. We thank all the reviewers for their valuable comments and special thanks to crystallographic reviewer to help us to improve the crystal structure of complex 4 .

\section{Notes and references}

1 (a) S. Trofimenko, Scorpionates: The Coordination of Poly(pyrazolyl)borate Ligands, Imperial College Press, London, 1999; (b) S. Trofimenko, Chem. Rev., 1993, 93, 943; (c) S. Trofimenko, Polyhedron, 2004, 23, 197; (d) C. Pettinari, Scorpionates II: Chelating Borate Ligands, Imperial College Press, London, 2008.

2 S. Trofimenko, J. Am. Chem. Soc., 1966, 88, 1842.

3 H. Vahrenkamp, Acc. Chem. Res., 1999, 32, 589.

4 (a) C. Slugovc, I. Padilla-Martınez, S. Sirol and E. Carmona, Coord. Chem. Rev., 2001, 213, 129; (b) C. Slugovc, R. Schmid and K. Kirchner, Coord. Chem. Rev., 1999, 185186, 109.

5 H. V. R. Dias and T. K. H. H. Goh, Polyhedron, 2004, 23, 273.

6 A. F. Hill, G. R. Owen, A. J. P. White and D. J. Williams, Angew. Chem., Int. Ed., 1999, 38, 2759.
7 (a) I. Kuzu, I. Krummenacher, F. Armbruster and F. Breher, Dalton Trans., 2008, 5836; (b) F.-G. Fontaine, J. Boudreau and M.-H. Thibault, Eur. J. Inorg. Chem., 2008, 35, 5439; (c) H. Braunschweig, C. Kollann and D. Rais, Angew. Chem., Int. Ed., 2006, 45, 5254.

8 (a) G. Dyson, A. Hamilton, B. Mitchell and G. R. Owen, Dalton Trans., 2009, 6120; (b) G. C. Rudolf, A. Hamilton, A. G. Orpen and G. R. Owen, Chem. Commun., 2009, 553; (c) G. R. Owen, H. P. Gould, J. P. H. Charmant, A. Hamilton and S. Saithong, Dalton Trans., 2010, 39, 392.

9 (a) G. Dyson, A. Zech, B. W. Rawe, M. F. Haddow, A. Hamilton and G. R. Owen, Organometallics, 2011, 30, 5844; (b) A. Zech, M. F. Haddow, H. Othman and G. R. Owen, Organometallics, 2012, 31, 6753.

10 (a) C. A. Kosky and P. Ganis, Acta Crystallogr., Sect. B: Struct. Crystallogr. Cryst. Chem., 1971, 27, 1859; (b) F. A. Cotton, M. Jeremic and A. Shaver, Inorg. Chim. Acta, 1972, 6, 543.

11 (a) V. Rodriguez, I. Atheaux, B. Donnadieu, S. Sabo-Etienne and B. Chaudret, Organometallics, 2000, 19, 2916; (b) S. L. Kuan, W. K. Leong, L. Y. Goh and R. D. Webster, J. Organomet. Chem., 2006, 691, 907; (c) G. C. Rudolf, A. Hamilton, A. G. Orpen and G. R. Owen, Chem. Commun., 2009, 553; (d) G. R. Owen, N. Tsoureas, R. F. Hope, Y.-Y. Kuo and M. F. Haddow, Dalton Trans., 2011, 40, 5906; (e) M. D. Spicer and J. Reglinski, Eur. J. Inorg. Chem., 2009, 1553.

12 (a) I. R. Crossley and A. F. Hill, Dalton Trans., 2008, 201; (b) N. Tsoureas, M. F. Haddow, A. Hamilton and G. R. Owen, Chem. Commun., 2009, 2538; (c) N. Tsoureas, T. Bevis, C. P. Butts, A. Hamilton and G. R. Owen, Organometallics, 2009, 28, 5222.

13 (a) E. Khaskin, P. Zavalij and A. N. Vedernikov, Angew. Chem., Int. Ed., 2007, 46, 6309; (b) E. Khaskin, P. Y. Zavalij and A. N. Vedernikov, J. Am. Chem. Soc., 2008, 130, 10088.

14 (a) K. Naktode, R. K. Kottalanka and T. K. Panda, New J. Chem., 2012, 36, 2280; (b) R. K. Kottalanka, K. Naktode and T. K. Panda, J. Mol. Struct., 2013, 1036, 188; (c) R. K. Kottalanka, K. Naktode, S. Anga, H. P. Nayek and T. K. Panda, Dalton Trans., 2013, 42, 4947; (d) R. K. Kottalanka, S. Anga, S. K. Jana and T. K. Panda, J. Organomet. Chem., 2013, 740, 104; (e) R. K. Kottalanka, S. Anga, K. Naktode, P. Laskar, H. P. Nayek and T. K. Panda, Organometallics, 2013, 32, 4473; (f) R. K. Kottalanka, K. Naktode, S. Anga and T. K. Panda, Phosphorus, Sulfur Silicon Relat. Elem., 2014, 189, 1624; $(g)$ R. K. Kottalanka, A. Harinath, J. Bhattacharjee, H. V. Babu and T. K. Panda, Dalton Trans., 2014, 43, 8757; (h) J. Bhattacharjee, R. K. Kottalanka, H. Adimulam and T. K. Panda, J. Chem. Sci., 2014, 126, 1463-1475.

15 Selected references for $\mathrm{Na} \cdots \mathrm{H}$ interactions $(a) \mathrm{H}$. Noth and S. Thomas, Eur. J. Inorg. Chem., 1999, 1373; (b) D. L. Reger, J. E. Collins, W. A. Flomer, A. L. Rheingold, C. Incarvito and L. A. Guzei, Polyhedron, 2001, 20, 2491; (c) H.-H. Giese, T. Habereder, H. Noth, W. Ponikwar, S. Thomas and M. Warchhold, Inorg. Chem., 1999, 38, 4188; (d) J. C. G. Ruiz, H. Noth and M. Warchhold, Eur. J. Inorg. 
Chem., 2008, 251; (e) L. Deng, H.-S. Chan and Z. Xie, J. Am. Chem. Soc., 2006, 128, 5219.

16 (a) S. Harder, Chem. Rev., 2010, 110, 3852; (b) S. Kobayashi and Y. Yamashita, Acc. Chem. Res., 2011, 44, 58.

17 (a) T. P. Hanusa, in Comprehensive Organometallic Chemistry III, ed. R. H. Crabtree and M. P. Mingos, Elsevier, Oxford, 2007, vol. 2, p. 67; (b) T. P. Hanusa, Organometallics, 2002, 21, 2559; (c) T. P. Hanusa, Chem. Rev., 2000, 100, 1023; (d) T. P. Hanusa, Coord. Chem. Rev., 2000, 210, 329.

18 K. Ruhlandt-Senge, K. Davis, S. Dalal, U. Englich and M. O. Senge, Inorg. Chem., 1995, 34, 2587.

19 I. K. Bezougli, A. Bashall, M. McPartlin and D. M. P. Mingos, J. Chem. Soc., Dalton Trans., 1997, 287.

20 P. Mikulcik, P. R. Raithby, R. Smith and D. S. Wright, Angew. Chem., Int. Ed. Engl., 1991, 30, 428.

21 (a) A. Cetin and C. J. Ziegler, Dalton Trans., 2006, 1006; (b) M. G. Davidson, C. T. O'Hara, M. D. Jones, C. G. Keir, M. F. Mahon and G. K. Köhn, Inorg. Chem., 2007, 46, 7686.

22 R. D. Shannon, Acta Crystallogr., Sect. A: Cryst. Phys., Diffr., Theor. Gen. Crystallogr., 1976, 32, 751.

23 M. G. Kunnath, W. Teng, W. Vargas and K. Ruhlandt-Senge, Inorg. Chem., 2005, 44, 4862.

24 R. Dennington, T. Keith and J. Millam, GaussView, Version 5, Semichem Inc., Shawnee Mission KS, 2009.

25 M. J. Frisch, G. W. Trucks, H. B. Schlegel, G. E. Scuseria, M. A. Robb, J. R. Cheeseman, G. Scalmani, V. Barone, B. Mennucci, G. A. Petersson, H. Nakatsuji, M. Caricato, X. Li, H. P. Hratchian, A. F. Izmaylov, J. Bloino, G. Zheng,
J. L. Sonnenberg, M. Hada, M. Ehara, K. Toyota, R. Fukuda, J. Hasegawa, M. Ishida, T. Nakajima, Y. Honda, O. Kitao, H. Nakai, T. Vreven, J. A. Montgomery Jr, J. E. Peralta, F. Ogliaro, M. Bearpark, J. J. Heyd, E. Brothers, K. N. Kudin, V. N. Staroverov, T. Keith, R. Kobayashi, J. Normand, K. Raghavachari, A. Rendell, J. C. Burant, S. S. Iyengar, J. Tomasi, M. Cossi, N. Rega, J. M. Millam, M. Klene, J. E. Knox, J. B. Cross, V. Bakken, C. Adamo, J. Jaramillo, R. Gomperts, R. E. Stratmann, O. Yazyev, A. J. Austin, R. Cammi, C. Pomelli, J. W. Ochterski, R. L. Martin, K. Morokuma, V. G. Zakrzewski, G. A. Voth, P. Salvador, J. J. Dannenberg, S. Dapprich, A. D. Daniels, O. Farkas, J. B. Foresman, J. V. Ortiz, J. Cioslowski and D. J. Fox, Gaussian 09, Revision B.01, Gaussian, Inc., Wallingford CT, 2010.

26 (a) D. Becke, J. Chem. Phys., 1993, 98, 5648; (b) C. Lee, W. Yan and R. G. Parr, Phys. Rev. B: Condens. Matter Mater. Phys., 1988, 37, 785.

27 M. F. Bush, J. Oomens, R. J. Saykally and E. R. Williams, J. Am. Chem. Soc., 2008, 130, 6463.

28 (a) U. Englich and K. Ruhlandt-Senge, Z. Anorg. Allg. Chem., 2001, 627, 851; (b) S. Chadwick, U. Englich, B. Noll and K. Ruhlandt-Senge, Inorg. Chem., 1998, 37, 4718.

29 M. Sheldrick, SHELXS-97, Program of Crystal Structure Solution, University of Göttingen, Germany, 1997.

30 G. M. Sheldrick, Acta Crystallogr., Sect. A: Found. Crystallogr., 2008, 64, 112. 